\title{
Otoimmün büllü hastalıkların klinik ve demografik özellikleri: 85 hastanın retrospektif analizi
}

\author{
Clinical and demographical features of autoimmune bullous diseases: \\ a retrospective analysis of 85 patients
}

\section{Ülker Gül, Arzu Kılıç, Seray Külcü Çakmak, Seçil Soylu*, Müzeyyen Gönül}

Sağlık Bakanlığı Ankara Numune Eğitim ve Araștırma Hastanesi, Dermatoloji Kliniği, Ankara, Türkiye

*Özel Lokman Hekim Hastanesi, Dermatoloji Kliniği, Ankara, Türkiye

\section{Özet}

Amaç: Otoimmün büllü hastalıklar, derideki spesifik antijenlere yönelik dokuda ya da kanda otoantikorların varlığı ile karakterize deri ve/veya mukoza tutulumu ile seyreden hastalıklar grubudur. Çalışmamızın amacı kliniğimize başvuran otoimmün büllü hastalıkların demografik ve klinik özelliklerini değerlendirmektir.

Yöntem ve Gereçler: 2003-2011 yılları arasında kliniğimize başvuran klinik, histopatolojik ve immunopatolojik kriterlere dayanılarak otoimmün büllü hastalıklar tanısı konan hastalar retrospektif olarak değerlendirildi. Olgular; cinsiyetleri, yaşları, otoimmün büllü hastalık tanısı, lezyonların başlangıç zamanı ve lokalizasyonu, tutulum yaygınlığı, eşlik eden hastalıklar, hastaların aldığı tedavi, tedaviye yanıtları açısından değerlendirildi. Bulgular: Çalışmamıza toplam 85 hasta alındı. Hastaların 49'u kadın (\%57,64), 36'sı erkekti (\%42,36). Olguların 57'si (\%67,05) pemfigus (P), 24 'ü ise $(\% 28,23)$ pemfigoid grubundaydı. Pemfigus vulgarisli olguların büllöz pemfigoidli olgulara oranı 3,16 olarak saptandı. Lezyonların başlangıç yaşları 22 ile 82 arasında değişiyordu ve kronisitesi 2 hafta ile 120 ay arasında değişiyordu. Olguların takipleri sırasında pemfigus vulgarisli bir olguya mide kanseri tanısı konuldu. Büllöz pemfigoidli üç olguda malinite eşlik ediyordu: Bir olgu kemik metastazlı opere meme karsinomu, bir olgu renal karsinoma ve bir olguda lenfoma mevcut idi. Bir olgu hariç tüm olgularımız klasik tedaviye yanıt verdi.

Sonuç: Çalışmamızda en sık pemfigus vulgarise rastladık, ancak pemfigus/büllöz pemfigoid oranını ise daha önceki çalışmalara göre daha düşük saptadık. Ayrıca otoimmün büllü hastalıkların çeşitli hastalıklarla birlikte görülebilme intimali nedeniyle detaylı araştııılmaları gerektiğini vurgulamak istiyoruz. (Türkderm 2014; 48: 7-12)

Anahtar Kelimeler: Pemfigus vulgaris, büllöz pemfigoid, otoimmün büllü hastalık

\section{Summary}

Background and Design: Autoimmune bullous dermatoses are a group of diseases characterized by the presence of autoantibodies in tissue or blood against specific cutaneous antigens. The aim of our study was to evaluate the demographical and clinical features of patients with autoimmune bullous diseases who applied to our clinic.

Materials and Methods: We retrospectively analyzed the patients who were diagnosed with autoimmune bullous diseases according to clinical, histopathological and immunopathological criteria between the years 2003 and 2011. The subjects were evaluated according to their sex, age, the type of autoimmune bullous disease, the onset and localization of lesions, the extensity of involvement, associated diseases, the treatment they were given and the response to the treatment.

Results: A total of 85 cases were included in our study. Fourty-nine (57.64\%) patients were female, 36 (42.36\%) were male. Fifty-seven cases (67.05\%) belonged to pemphigus (P) group and 24 (28.23\%) to pemphigoid. The ratio of patients with pemphigus vulgaris to the patients with pemphigoid was found to be 3.16. The age range of the onset of the symptoms was between 22 and 82 years old. The duration of the lesions

Yazışma Adresi/Address for Correspondence: Dr. Arzu Klıç, Sağlık Bakanlığı Ankara Numune Eğitim ve Araştırma Hastanesi, Dermatoloji Kliniği, Ankara, Türkiye Tel.: +90 3125085638 E-posta: kilicarzu@gmail.com Geliş Tarihi/Received: 22.01.2013 Kabul Tarihi/Accepted: 03.05.2013 
was between 2 weeks and 120 months. On follow up, a patient with pemphigus vulgaris was diagnosed as having gastric carcinoma. Bone metastasis was detected in one patient with bullous pemphigoid who was operated for breast carcinoma previously. Renal cell carcinoma and lymphoma were detected in two patients with bullous pemphigoid. All patients, except one, responded to therapy.

Conclusion: In our study, the frequent disease was P.vulgaris, but the ratio of pemphigus/bullous pemphigoid was found to be lower than previous studies. Besides, we want to emphasize that detailed investigations due to the possibility of the presence with other diseases. (Turkderm 2014; 48: 13-6)

Key Words: Pemphigus vulgaris, bullous pemphigoid, autoimmune bullous disease

\section{Giriş}

Otoimmün büllöz hastalık $(\mathrm{OBH})^{\prime}$ lar deride bulunan çeşitli otoantijenlere karşı otoantikorların oluşması sonucunda klinik olarak oral mukozada ve/veya deride vezikülobülöz lezyonlarla karakterize nadir görülen bir grup hastalıktır'-3. OBH'lar bül oluşumunun seviyesine bağlı olarak intraepidermal ya da supepidermal OBH'lar olmak üzere iki ana gruba ayrılırlar ${ }^{4}$. Intraepidermal $\mathrm{OBH}^{\prime} l a r d a$ hedef protein epidermiste keratinositler arası adezyonu sağlayan desmogleinler olup, temel patolojik görüntü akantolizdir 1,3,4. Intraepidermal OBH'ları pemfigus grubu hastalıklar oluşturur. Bunlar; pemfigus vulgaris (PV), pemfigus vejetans (Pvej), pemfigus foliaseus (PF), pemfigus eritematozus (PE), IgA pemfigusu, pemfigus herpetiformis $(\mathrm{PH})$, paraneoplastik pemfigus (PNP) ve ilaca bağlı pemfigusdur ${ }^{4}$. Subepidermal $\mathrm{OBH}^{\prime}$ lar ise pemfigoid grubu hastalıklar ve dermatitis herpetiformis (DH)'i kapsamaktadır. Pemfigoid grubu hastalıkları; büllöz pemfigoid (BP), pemfigoid gestasyones (PG), muköz membran pemfigoidi (MMP), edinsel epidermolizis bülloza (EEB), liken planus pemfigoides (LPP) ve lineer IgA dermatozu (LAD) oluşturur ${ }^{4,5}$. Pemfigoid grubu hastalıklarda hedef antijenler dermalepidermal bileşkede yer alırken, $\mathrm{DH}^{\prime}$ de hedef antijen epidermal transglutaminazdır2,4,5.

Önemli bir morbidite ve mortalite nedeni olabilen $\mathrm{OBH}^{\prime}$ lar tüm dünyada görülmekle birlikte epidemiyolojisi ve sıklığını inceleyen çeşitli çalışmalarda belirgin farklılıklar bildirilmiştir6-10. Ülkemizde $\mathrm{OBH}^{\prime}$ ların sıklığını, demografik ve klinik özelliklerini bildiren az sayıda çalışma mevcuttur ${ }^{11-13}$.

Çalışmamızın amacı kliniğimize başvuran $\mathrm{OBH}^{\prime}$ lı olguların demografik ve klinik özelliklerini değerlendirmektir.

\section{Gereç ve Yöntem}

Kasım 2003-Şubat 2011 yılları arasında kliniğimize başvuran OBH tanısı konulmuş olgular retrospektif olarak tarandı. Hastalara konulan $\mathrm{OBH}$ tanısının alt tipi hastaların klinik özelliklerine, lezyonların histopatolojik ve direkt immünfloresan (DiF) inceleme tetkiklerine dayanılarak tespit edildi. DiF incelemesinde herhangi bir boyanma saptanmayan hastalar çalışmaya dahil edilmedi. Olguların hiçbirine indirekt immünfloresan ve tuzda ayrıştırılmış deride immünfloresan incelemeleri yapılamadı. Otoimmün büllü hastalıkların alt tipinin belirlenmesinde kullanılan tanı kriterleri şunlardı: Pemfigus grubu hastalıklar için klinik olarak mukozal erozyonların, deride gevşek vezikül, bül, erode alanların, vejetatif plakların varlığı, Nikolski bulgusunun varlığı, lezyonların yerleşim yerleri ve yerleşim paternleri, histopatolojik olarak akantolizin

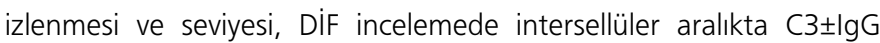
birikimi esas alındı. PV için başta oral kavite olmak üzere mukozal tutulumun olması ve bülün suprabazal yerleşmesi, PF için skuamlı ve krutlu erozyonların seboreik bölgere dağılımı, bülün subkorneal ya da stratum granulozumda gözlenmesi, PE için klinik olarak yüz ve gövde üst kısmında yerleşen eritemli skuamlı plaklar, antinükleer (ANA) antikor pozitifliği, IgA pemfigusu için klinikte anüler, sirsine dağılımlı vezikülopüstüllerin varlığı ve $\mathrm{DIF}^{\prime}$ de intersellüler IgA birikimi, $\mathrm{PH}$ için klinik olarak eritemli ürtikeryen papüller, herpetiform paternli veziküller, histopatolojik olarak seyrek akantoliz oluşumu esas alındı ${ }^{1,4,14-16}$.

Pemfigoid grubu hastalıkların tanısında esas alınan kriterler şunlardı: BP için gergin vezikülobüllerin-ürtikeryen lezyonların varlığı, histopatolojik olarak subepidermal ayrılmanın olması, hem bül kavitesi hem de dermisde eozinofillerin varlığı, DiF incelemede bazal membran zonunda (BMZ) lineer C3 \pm lgG birikiminin gözlenmesi, MMP için klinik olarak deri ve mukozalarda (oral-konjuktival-genital) skatris bırakan vezikülobüllöz lezyonlar, histopatolojik olarak eozinofil yoğunluğunun az olması ve epidermis altında lameller tarzda fibrozisin varlığı tanıda kullanıldı 2,4,5. LPP klinik olarak liken planusda görülene benzer likenoid papüller, bu papüllerin üzerinde ya da normal deride büllerin varlığı, histopatolojik olarak liken planus ve BP'nin patolojik görünümü, DiF incelemede $B M Z^{\prime}$ de lineer $C 3 \pm \lg G$ birikimi tanıda kullanıldı. $B M Z^{\prime}$ de lineer IgA depolanması LAD, dermal papilla uçlarında granüler IgA varlığı DH lehine kabul edildii,5.

Otoimmün büllü hastalık tanısı alan tüm hastalar yaş, cinsiyet, şikayetlerin başladığı yaş ve lokalizasyon, lezyonları indükleyen bir faktör olup olmadığı, öncesinde eşlik eden hastalık ve/veya ilaç kullanımın varlığı, büllü hastalığa eşlik eden sistemik hastalıklar açısından sorgulandı. Tanı konulan $\mathrm{OBH}$ alt tipi ve hastalara başlanan tedavi ve hastalıklarının tedaviye verdikleri yanıtları kaydedildi.

\section{Bulgular}

Çalışma grubunu 85 hasta oluşturuyordu. Hastaların 49'u $(\% 57,64)$ kadın, 36'sı $(\% 42,36)$ erkekti. Olguların alt gruplara göre yaş ve cinsiyet özellikleri, hastalık başlangıç ve başvurma yaşları Tablo 1'de görülmektedir. Seksen beş olgunun 57'si $(\% 67,05)$ pemfigus grubundaydı. Pemfigus grubundaki 57 olgunun 44'ü $(\% 77,19)$ PV, 8'i $(\% 14,03)$ PF, 2'si $(\% 3,5)$ PVej, biri $(\% 1,75) \mathrm{PE}$, biri $(\% 1,75) \mathrm{PH}$ ve biri $(\% 1,75)$ de IgA pemfigusuydu.

Olguların 24'ü $(\% 28,23)$ pemfigoid grubundaydı, 18'i $(\% 81,81)$ BP, ikisi $(\% 9,09)$ MMP, ikisi $(\% 2,35)$ LAD'u, biri $(\% 4,54)$ PG, biri de $(\% 4,54)$ LPP tanılarına sahipti. BP'li olgularımızdan biri pretibial bölgede lokalize nodüler lezyonlarla kliniğimize başvurdu. Hastanın başlangıçta herhangi bir bülü yoktu. Histopatolojik incelemesi prurigo nodularis olarak raporlandı, yapılan DiF incelemesinde BMZ' de IgG ve C3 depolanması izlendi ve hastaya pemfigoid nodularis tanısı kondu ve hastanın takiplerinde bülleri oluştu. Ayrıca tüm $\mathrm{OBH}^{\prime}$ ların içinde 4 $(\% 4,70)$ olguda DH tespit edildi. Olguların hiçbirinde büllöz hastalığı tetikleyen bir ilaç kullanıma rastlanılmadı.

Tüm OBH'lar değerlendirildiğinde olgularımızda sıklık sırasına göre PV $(\% 51,76)$, BP $(\% 21,17)$, PF $(\% 9,41)$ gözlendi. 
Tablo 1. Alt gruplara göre cinsiyet ve yaş özellikleri

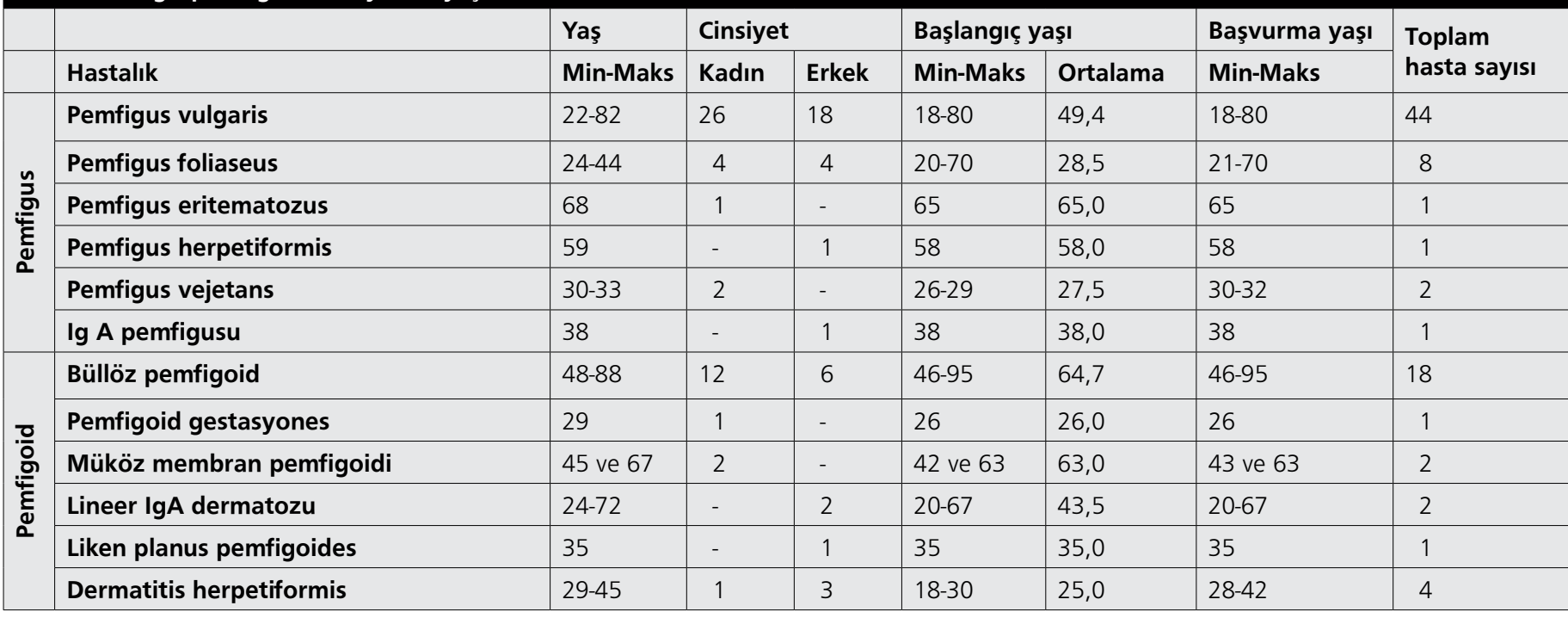

Tablo 2. Pemfigus grubu hastalardaki, başlangıçtaki ve ilk muayenedeki tutulum yerleri

\begin{tabular}{|c|c|c|c|c|c|c|}
\hline \multirow{2}{*}{$\begin{array}{l}\text { Semptomların ilk başlangıç } \\
\text { yerleri }\end{array}$} & \multicolumn{6}{|c|}{ Pemfigus } \\
\hline & PV (n) & PVej (n) & PF (n) & $\operatorname{PE}(n)$ & $\mathrm{PH}(\mathrm{n})$ & IgA pemfigusu ( $n$ ) \\
\hline Oral mukoza & 35 & 0 & 0 & 0 & 0 & 0 \\
\hline Deri & 5 & 2 & 8 & 1 & 1 & 1 \\
\hline Oral mukoza+deri & 4 & 0 & 0 & 0 & 0 & 0 \\
\hline \multicolumn{7}{|c|}{ Kliniğimize başvurduklarındaki tutulum yerleri } \\
\hline Oral mukoza & 8 & 0 & 0 & 0 & 0 & 0 \\
\hline Genital mukoza & 2 & 0 & 0 & 0 & 0 & 0 \\
\hline Deri & 2 & 2 & 8 & 1 & 0 & 1 \\
\hline Oral mukoza+deri & 32 & 0 & 0 & 0 & 1 & 0 \\
\hline
\end{tabular}

Tablo 3. Otoimmün büllü hastalıklara eşlik eden hastalıklar

\begin{tabular}{|l|l|l|}
\hline Otoimmün büllü hastalık & $\mathbf{n}$ & Eşlik eden hastalıklar \\
\hline \multirow{2}{*}{ Pemfigus vulgaris } & 1 & Toksik diffüz guatr \\
\cline { 2 - 3 } & 1 & Hashimato tiroiditi \\
\cline { 2 - 3 } & 1 & Nodüler guatr \\
\cline { 2 - 3 } & 1 & Akciğer tüberkülozu \\
\hline Pemfigus foliaseus & 1 & Graves hastalığı \\
\hline Büllöz pemfigoid & 1 & Graves hastalığı \\
\hline & 1 & Serebrovasküler hastalık (SVH) \\
\hline & 1 & SVH+hipertansiyon+epilepsi \\
\hline & 1 & Renal karsinom \\
\hline & 1 & Meme karsinomu \\
\hline & 1 & Lenfoma \\
\hline Dermatitis herpetiformis & 1 & Pangastrit ve duodenit \\
\hline
\end{tabular}

Çalışma grubumuzu oluşturan 85 olgu içinde PNP, EEB ve çocukluk çağı OBH olgusuna rastlanılmadı.

Pemfigus vulgaris kadınlarda daha sık olarak $(K / E=1,44)$, PF ise kadın ve erkeklerde eşit olarak izlendi. BP'de kadın olgularımızda daha sık saptandı $(K / E=2)$
Genel değerlendirmede olguların şikayetlerinin başlangıç yaşları 22 ile 82 arasında değişiyordu. PV'li olguların şikayetlerinin başlangıç yaş ortalaması 49,4 iken, BP'de ortalama başlangıç yaşı 64,7 olarak saptandı. Olguların kliniğimize başvurmadan önce mevcut şikayetlerinin kronisitesi 2 hafta ile 120 ay arasında değişiyordu. Üç PV olgusu dışında olguların hepsine tanı ilk defa kliniğimizde konuldu. Lezyonların başlangıç yeri sorgulandığında; pemfigus grubunu oluşturan 57 olgunun 35'inde lezyonlarının $(\% 61,4)$ oral mukozada, $18^{\prime}$ inde $(\% 31,57)$ deride, 4 'ünde $(\% 7,01)$ ise hem oral mukoza hem deride başladığı öğrenildi. Kliniğimize başvurduklarında ise yapılan dermatolojik muayenede olguların 33'ünde $(\% 57,89)$ hem deri hem mukozal tutulum, 14 'ünde $(\% 24,56)$ sadece deri ve $10^{\prime}$ unda $(\% 17,54)$ sadece mukoza tutulumu saptandı (Tablo 2).

Müköz membran pemfigoidli iki kadın olgumuzdan birinde başlangıç bölgeleri oral ve konjuktival mukoza; diğerinde genital mukoza ve deride idi, Olgulardan ilki bize başvurduğunda oral+konjuktival+genital mukoza tutulumu mevcuttu. Diğer MMP'li olgumuzda başlangıç yeri genital mukoza ve deri, bize başvurduğunda oral mukoza, genital mukoza ve deri tutulumu mevcuttu. Diğer pemfigoid grubu hastalarımızda başlangıç yeri deri tutulumu idi. BP'li olgularımızda deri lezyonlarını eritemli ürtikeryen plaklar ve büller oluşturmaktaydı. 
Pemfigoid grubu olgular bize başvurduklarında BP'li bir olguda deri tutulumuna oral mukoza tutulumu eklenmişti. LAD'li bir olgumuzda hastalığın başlangıç bölgesi oral mukozada gözlenen veziküler ve erode lezyonlardı. DH'li olgularımızın lezyonlarının başlangıç yeri deriydi.

Eşlik eden hastalıklar araştırıldığında; PV'li bir olguda akciğer tüberkülozu, bir olguda toksik diffüz guatr, bir olguda nodüler guatr, bir olguda ise Hashimato tiroiditi gözlendi. PF'li bir olgumuzda Graves hastalığı saptandı. PV'li bir olguda hastalık öncesi çok sayıda (100'e yakın) arı sokması öyküsü bulunuyordu. İki BP'li olguda serebrovasküler hastalık (birinde buna epilepsi ve hipertansiyon da eşlik ediyordu), bir BP'li olguda Graves hastalığı, bir BP'li olguda opere meme karsinomu ve bir BP'li olguda lenfoma bulunuyordu (Tablo 3).

Malinite yönünden incelendiğinde 85 olgunun 4'ünde malinite gözlendi. PV nedeniyle takip edilirken bir olguda mide kanseri tanısı konuldu. Pemfigus olgularımızda klinik olarak PNP kliniğini düşündürecek bulgular, histopatolojik ve DiF bulguları yoktu. Opere meme karsinomlu BP'li bir olguda kemik metastazı, diğer bir olgumuzda renal karsinoma ve bir olguda da lenfoma mevcuttu. DH'li olgularda lenfoma ve diğer malinitelere rastlanmadı. DH'li bir olgumuzda duedonit ve pangastrit saptandı.

Olguların 51'i düzenli olarak takip edildi. Ortalama takip süresi $19,6 \pm 6,2$ aydı.

Pemfigus grubu içinde yer alan PV'li olgularımızda lezyonlarının şiddetine ve yaygınlığına göre standart tedavi olarak 1-1,5 mg/kg/ gün prednizolon ve $1-3 \mathrm{mg} / \mathrm{kg} /$ gün azatiyopürin başlandı. Olguların çoğunluğunda klasik standart tedaviyle semptomları geriledi. Hastalık aktivasyon bulguları göstermeyen tüm olgularda kortikosteroid dozu kademeli olarak düşüldü. Ancak üç pemfiguslu olguda oral kortikosteroid tedavisine yan etki gelişmesi (İki olguda myopati, bir olguda glokom) ve bir olguda da yanıt alınamaması nedeni ile tedavi değiştirildi ve intravenöz immünoglobulin (IVIG) tedavisine başlandı. Myopati ve glokom gelişen üç olguda kortikosteroid dozu azaltılarak ayda bir kez IVIG tedavisi başlandı ve olgular toplam da 6 kür IVIG tedavisi aldı, takiplerinde hastaların yeni çıkan lezyonları olmadı. Kortikosteroid tedavisine yanıt alınamayan diğer bir olguda 2 kür IVIG tedavisine kısmi yanıt alındı, ancak hastaya önerilen diğer tedavileri kabul etmeyerek takibimizden çıktı.

Pemfigus herpetiformisli bir hastamızda ise klasik tedaviye yeterli yanıt alınamaması nedeni ile kortikosteroid tedavisine 100 mg/gün dapson eklendi. Bu hasta halen takibimizde olup düşük doz kortikosteroid ve dapson 100 mg/gün tedavisi ile remisyon altındadır.

Pemfigus foliaseuslu 8 olgumuzda düşük doz oral kortikosteroid, topikal steroid tedavileri ile olguların hepsinde remisyon sağlandı.

Pemfigoid grubunu oluşturan olgulara (bir olgu hariç) 40-80 mg/ gün prednizolon ve 100-150 mg/gün azatiyopürin tedavisi başlandı. Takip edilen olguların tümünün bu tedaviye yanıtı iyiydi. Nodüler pemfigoidli olgumuzun yaşının ileri olması ve ayrıca eşlik eden sistemik hastalıklarının olması nedeniyle tetrasiklin 4x500 mg/gün, nikotinamid $3 \times 500 \mathrm{mg} /$ gün ve topikal steroid tedavileri başlandı. Bu olgunun lezyonları 1 ayda tamamen geriledi. MMP'li iki olgumuzda başlanan $1 \mathrm{mg} / \mathrm{kg} /$ gün oral prednisolon ve $150 \mathrm{mg} /$ gün azatiyopürin tedavisine yanıt alındı ve olgular göz bölümü ile birlikte takip edildi. Dermatitis herpetiformisli ve LAD'li olgular dapson 100 mg/gün tedavisi ile kısa sürede kontrol altına alındı.
Pemfigus ve pemfigoid olgularına verilen oral kortikosteroid ve immünsüpresif tedavilerin yan etkisi olarak olguların çoğunda kilo artışı, kushingoid görünüm, oral kandidiazis gibi kortikosteroid kullanımına bağlı beklenen yan etkiler gözlenirken major yan etkiler olarak bir olguda gastrointestinal kanama, iki olguda myopati, bir olguda glokom, bir olguda tromboemboli gelişti. Bunlardan PV olgularının 3'ünde $(\% 6,81)$ oral kortikosteroid tedavisinin kesilmesini gerektirecek komplikasyonlar gelişti (2 olguda myopati, bir olguda glokom). Bir PV olgusunda oral kortikosteroid ve oral azatiyopürin tedavisine yanıt alınamadı. PV'li bir olgumuzda gastrointestinal kanama gelişti, hasta yoğun bakım şartlarında gastroenteroloji kliniğiyle takip edilerek gastrointestinal kanaması kontrol altına alındı ve tedavisinde değişiklik yapılmadı. Bir PV'li olgumuzda ise takipleri sırasında mide adenokarsinomu tanısı konuldu, bu hasta daha sonra mide karsinomuna bağlı olarak eksitus olmuştur. Bunun dışında takip altında olan hastalarımızın hiçbirinde mortalite gözlenmedi.

\section{Tartışma}

Kliniğimize başvuran $\mathrm{OBH}^{\prime}$ lı olgular bütün olarak değerlendirildiğinde olgularımızın çoğu pemfigus grubuna aitti. Bunu pemfigoid grubu ve DH takip ediyordu. Bu konuyla ilgili olarak ülkemizde yapılan en geniş seri sadece pemfiguslu 148 olgunun incelendiği Uzun ve ark.'nın çalışmasıdır ${ }^{11}$. Ülkemizde yapılan diğer bir çalışma ise Demircioğlu ve arkadaşlarının yaptıkları PV tanısı almış 32 hastanın genel klinik özellikleri ve tedaviye yanıtlarını değerlendirdikleri çalışmadır ${ }^{12}$. Uzun ve ark.'nın çalışmalarında 148 olgu içinde en sık \%83,1 oranıyla PV, takiben olguların \%9,5'inde PF, \%4'ünde PE gözlenmiş ve pemfiguslu olguların BP'li olgulara oranını 5,1 olarak saptamışlardır ${ }^{11}$. OBH'ların toplumda görülme sıklığı etnik ve coğrafik değişikliklere göre farklılıklar göstermektedir. Daneshpazhooh ve ark.'ı İran'da yaptıkları çalışmalarında 1402 olgu içinde en sık olarak PV $(\% 81,2)$, ikinci sıklıkta \%11,6 oranıyla BP saptamışlardır. Nanda ve ark.'nın Kuveyt'de yaptıkları çalışmalarında benzer şekilde en sık olarak PV saptanmıştır. Farklı olarak Marazza ve ark.'nın İsviçre'de yaptıkları prospektif çalışmalarında ise BP $(\% 83,3)$ pemfigus grubu hastalıklara göre daha sık bildirilmiştir ${ }^{10}$. Schmidt ve ark.'ı derlemelerinde Avrupa'da son 10 yılda BP'nin insidansının 2-5 kat artış gösterdiğini bildirmişlerdir ${ }^{5}$. Biz çalışmamızda kliniğimize başvuran $\mathrm{OBH}^{\prime}$ lar içinde en sık pemfigus grubu hastalıkları $(\% 67,05)$ saptadık. Pemfigus grubunu oluşturan 57 olgunun ise \%77,19'u PV, \%14,03'ünü PF, \%3,5'ini PVej, \%1,75'ini $\mathrm{PE}, \% 1,75^{\prime}$ ini $\mathrm{PH}, \% 1,75^{\prime}$ ini IgA pemfigusu oluşturuyordu.

Tüm OBH'lar içinde en sık PV\%51,76 oranında, daha sonra BP $(\% 21,17)$ ve PF $(\% 9,41)$ gözlendi. Bu bulgu göze alındığında çalışmamızda her ne kadar PV'ye daha sık rastlanmış olsa da pemfiguslu olguların BP'li olgulara oranı, Uzun ve ark.'nın çalışmalarındakine göre daha düşük bulundu. Pemfigus/ BP oranı Uzun ve ark.'nın çalışmalarında 5,1 olarak saptanırken ${ }^{11}$ çalışmamızda pemfigus/ BP oranı 3,16 olarak bulunmuştur. Marazza ve ark.'nın İsviçre'de son yıllarda yaptıkları 2 yılı içeren prospektif çalışmalarında BP'yi (hastaların \%83,3'ü) en sık, PV ve PF'yi daha az sıklıkta saptamışlardır . Son yıllarda özellikle Avrupa'dan bildirilen çalışmalarda BP insidansının yüksek olduğu dikkat çekmektedir ${ }^{4 \cdot 6}$. Çalışmamızda saptadığımız pemfigus/BP oranı, ülkemizin bu konuda yapılan en geniş serisine ait Uzun ve ark.'nın saptadığı orana göre düşük bulunması nedeniyle BP sıklığında bir artış olması lehine yorumlanabilir. Bu artış BP'nin bir yaşıııı hastalığı 
olması sebebiyle ülkemizde artmış olan ortalama yaşam süresiyle açıklanabilir.

Pemfigus, her yaş ve ırkta görülebilmekle birlikte en sık 40-60 yaşları arasında izlenmektedir. Prevalansı kadın ve erkeklerde eşit olarak bildirilmiştir ${ }^{1,3,16}$. Uzun ve ark.'I, PV'de erkek/kadın oranını 1/1,41 olarak saptamışlardır. Olguların \%8,12'sinde sadece mukoza, $\% 4,9^{\prime}$ unda sadece deri ve \%86,2'sinde hem deri hem mukoza tutulumu saptamışlardır ${ }^{11}$. Michailidou ve ark.'ı Yunanistan'da yaptıkları ve 129 PV hastasını içeren çalışmalarında erkek/kadın oranını 1/2,25 olarak saptamışlardır ${ }^{17}$. Ayrıca olguların \%86,1'inde sadece oral mukoza tutulumu, \%13,3'ünde oral mukoza ve deri tutulumu,\%1,3'ünde oral mukoza, göz ve deri tutulumu tespit etmişlerdir ${ }^{17}$.

Çalışmamızda literatür ile uyumlu olarak PV'de ortalama başlangıç yaşını 49,4, PF' de ise 28,5 olarak saptandı11,16. PE'li 65 yaşında 1 olgu dışında hastalıkların başlangıç yaşları literatür ile uyumlu bulundu. PV kadınlarda daha sık olarak $(K / E=1,44)$, PF ise kadın ve erkeklerde eşit olarak izlenmiştir. Çalışmamızda pemfigus grubunu oluşturan 57 olgunun \%61,4'ünde lezyonların oral mukozadan, \%31,57'sinde deriden, \%7,01'inde hem mukozada hem deride başladığı öğrenildi. Kliniğimize başvurduklarında ise yapılan dermatolojik muayenede olguların çoğunluğunda (\%57,89'unda) hem deri hem mukozal tutulum saptandı.

Uzun ve ark.'nın yaptıkları çalışmalarında PV için hastalığın başlangıç semptomları ile kesin tanı arasında geçen süre ortalama 20 ay olarak belirtilmiştir ${ }^{11}$. Woldegiorgis ve ark. çalışmalarında tanı gecikme süresini PF için ortalama 6 ay, PV için ortalama 4,5 ay olarak saptamışlardır ${ }^{18}$. Scully ve ark.'ı I PV'de semptomların başlangıcı ve tanı konması arasındaki ortalama süreyi 6 ay olarak tespit etmişlerdir ${ }^{19}$. Her ne kadar hastalarımızın öyküsünden, hastaların ilk şikayetlerinin başlangıcı ile ilk hekim başvurusu ve ilk dermatoloğa başvurma süreleri ve kesin tanı konulana kadar geçen süre öğrenilemese de verilerimize göre hastaların ilk lezyon çııısının çoğunlukla oral mukozadan başlayıp, kliniğimize başvurduklarında ise çoğunluğunda hem deri hem mukoza tutulumunun bulunması tanıdaki gecikmeye işaret etmektedir.

Büllöz pemfigoidde hastalığın başlangıç yaşı 60'ın üzeridir ${ }^{5}$. Demircioğlu çalışmalarında, erkeklerde kadınlardan 2 kat daha fazla saptamışken 12, Marazza ve ark.'nın çalışmasında kadın/erkek oranı 1,3 olarak tespit edilmiştir ${ }^{10}$. Akay ve ark. çalışmalarında hastalığın ortalama başlangıç yaşını 78,8 yıl ve kadın/erkek oranını 1,58 olarak saptanmışlardır ${ }^{13}$. Bizim çalışmamızda ortalama başlangıç yaşı 64,7 olarak ve kadın/erkek oranı ise $2 \mathrm{idi}$. Altmış yaş civarında başlayan ve kadınlarda 2 kat daha sık olan MMP'de çalışmamızda 67 yaşında ve 45 yaşlarında 2 kadın olguda rastladık.

Dermatitis herpetiformis genellikle 20-40 yaşları arasında başlamaktadır. Kadın ve erkeklerde eşit olarak görülür². Çalışmamızda da ortalama yaş 25 olarak saptanmıştır. Erkek hastalarda ise daha fazla izlenmiştir (1 kadın, 3 erkek).

Otoimmün büllü hastalıkların bazı hastalıklar ile birlikteliği bulunabilir5,16,20. PV ve PF myastenia gravis, timoma veya her ikisiyle birlikte izlenebilir1,3,20. Younus ve ark.'nın çalışmasında pemfigusun neoplazilerle olan ilişkisine değinilmiş, yapılan literatür taramasında PV'nin özellikle nontimik neoplazilerle; PF ya da PE'nin ise timik neoplazilerle birlikteliği üzerinde durulmuştur ${ }^{21}$. Michailidou ve ark.
PV olgularının 75'inde eşlik eden hastalıkların varlığını bildirmişlerdir. Bunların \%8'inde diyabet, \%20'sinde hipertansiyon, \%2,6'sında tiroid patolojileri, \%13,3'ünde alerjik reaksiyonlar ve $\% 6,4$ 'ünde kandida saptanmışıı ${ }^{17}$. Uzun ve ark.'nın yaptıkları çalışmada pemfigusa eşlik eden hastalıklar içinde en sık otoimmün tiroid hastalıkları saptamışlar. Ayrıca bir PF'li olguda püstüler psöriazis, iki PNP'li olguda sırasıyla bronşial karsinom ve retroperitoneal yerleşimli lenfoma saptamışlardır ${ }^{11}$. Ulusal ve ark.'nın psoriazis ve BP birlikteliğine işaret eden olguları mevcuttur ${ }^{22}$. Çalışmamızda bir olguda akciğer tüberkülozu, bir olguda toksik diffüz guatr, bir olguda nodüler guatr, bir olguda ise daha önceden tarafımızdan rapor edilmiş Hashimato tiroiditi ${ }^{23}$ mevcuttu. Pemfiguslu olgularımız içinde tiroid patolojisi oranı \%7,01 idi. Yine daha önceden rapor edilmiş iki pemfiguslu olgumuzdan birisinde hastalık öncesi çok sayıda (100'e yakın) arı sokması öyküsü mevcutken diğerinde ise takipleri sırasında mide adenokarsinomu geliştiti ${ }^{2425}$.

Büllöz pemfigoid otoimmün, nörolojik ve maliniteler gibi çeşitli hastalıklar ile birlikte görülebilir ${ }^{5,20,26}$. BP'nin malinitelerle olan birlikteliği halen tartışmalı olsa da, bu birlikteliğe ait yayınlar az değildir ${ }^{27-29}$. Bu konuyla ilgili en geniş seri Lindelöf ve ark.'nın 497 hasta ile yaptıkları çalışmalarında BP ile malinetesi arasında bir ilişki saptanamamıştır ${ }^{30}$. Çalışmamızda BP'li üç olguya $(\% 13,64)$ malinite eşlik ediyordu: Bir olguda kemik metastazlı meme kanserii $^{29}$, diğer bir olgumuzda renal karsinoma ve bir olguda da lenfoma saptandı. BP'ye eşlik edebilecek diğer bir hastalık nörolojik hastalıklardır ${ }^{20,26}$. Literatürde çeşitli nörolojik hastalığı olan olgularda BP gelişimi bildirilmiş ve bu 2 hastalık grubu arasında bir ilişki olabileceği öne sürülerek, bu olgularda BP prognozunun daha kötü olduğu vurgulanmıştır ${ }^{20}$. Guo ve ark. BPAG1 ve BP ilişkisini araştırmayı amaçladıkları çalışmalarında, BPAG1 geni uzaklaştııımış sıçanlarda ciddi distoni ve sensörial sinir dejenerasyonu geliştiğini saptamışlardır ${ }^{3}$ Çalışmamızda iki BP'li olgumuzda kısa süre öncesinde geçirilmiş serebrovasküler olay öyküsü bulunmaktaydı. Olguların birinde epilepsi ve hipertansiyon da eşlik ediyordu. Marzano ve ark. yaptıkları bir çalışmada koagülasyon kaskadının aktive olduğunu, hiperkoagülabilitenin inflamasyon, bül formasyonu ve tromboz oluşumuna neden olduğu ve bu durumun hastalık şiddeti ile ilişkili olabildiğini savunmuşlardır ${ }^{32}$. BP'ye eşlik edebilen hastalıklar yaş ile de sıklığında artış olan hastalıklardır, bu nedenle birliktelik rastlantısal olabilir. Her ne kadar halen tartışmalı olsa da, çalışmamızda BP'li iki olguda serebrovasküler olay öyküsünün bulunması, üç olguda malinite varlığı BP ile bu hastalıklar arasında ilişkinin olabileceğini düşündürmektedir.

Özellikle PV'de tanıda gecikme süresi prognozu doğrudan etkilemektedir. Pemfigus hastalarının çoğunlukla şikayetleri oral mukozadan başladığı ve çoğunlukla bu semptomları nedeniyle dermatolog dışı hekimlere başvurdukları için hastalıklarının tanısında gecikme söz konusudur ${ }^{11,16}$. Her ne kadar pemfigus hastalarımızın öykülerinden hastaların ilk şikayetlerinin başlangıcı ile kesin tanı arasında geçen süre öğrenilemese de verilerimize göre hastaların ilk lezyon çıkışının çoğunlukla oral mukozadan başlayıp kliniğimize başvurduklarında ise hem deri hem de mukoza tutulumunun bulunması tanıdaki gecikmeye işaret etmektedir.

Otoimmün büllü hastalıklarda mortalite araştırıldığında Risser ve ark.'nın 1979 ile 2002 yılları arasında büllü hastalık mortalite 
oranını değerlendirdikleri çalışmalarında büllü hastalıklar içinde 1979 yılından 2002 yılına kadar mortalite oranının stabil kaldığını, bu period süresince pemfigoidde mortalite oranı artarken, pemfigusta düştüğünü tespit etmişlerdir ${ }^{33}$. Uzun ve ark.'ı pemfigus olgularında mortalite oranını \%4,8 olarak saptamışlardır, ölümlerin esas nedeni olarak rezistan bakterilere bağlı kutanöz ve pulmoner infeksiyonlar ve akabinde gelişen sepsis olarak bildirmişlerdir ${ }^{11}$. Çalışmamızda bir PV'li olgu dışında hiçbir olgumuzda mortalite gözlenmedi. Eksitus olan bu olgumuzda ölüm nedeni mide adenokarsinomuna bağlıydı. Olgularımızın 35'inin takipten çıkması ve takip altında olan olgularda da esas mortalite kaynağı olan dirençli infeksiyonlar ya da sepsisin gözlenmemesi çalışmamızda mortalite saptamamızın nedeni olabilir. Çocuklarda $\mathrm{OBH}^{\prime}$ lar nadir görülmektedir. Kharfi ve ark.'। Tunus'da üçüncü basamak bir hastanede toplam 32 yıllık gözlemlerini içeren çalışmalarında $\mathrm{OBH}$ tanısı alan 47 çocuk olgu saptamışlardır ${ }^{34}$. Biz çalışmamızda çocuk $\mathrm{OBH}$ olgusuna rastlamadık. Hastanemizde pediatri kliniği bulunmadığı için pediatrik dermatolojik hastalıkları hastanemizde nispeten daha az görülmektedir. Bu bağlamda zaten az sıklıkta gözlenen çocukluk çağının kronik büllöz hastalığı olgusuna ya da herhangi başka bir OBH'lı çocuk olguya rastlanılmadı.

Sonuçları açısından çalışmamızı değerlendirdiğimizde olgularımız içinde en sık PV'ye rastladık. Ülkemize ait geniş bir seriyi içeren Uzun ve ark.'nın bulgularından farklı olarak Pemfigus/BP oranını ise daha düşük olarak saptadık. Bu sonuçlara dayanarak Avrupa ülkelerindeki oranlarla karşılaştııllığında PV'nin ülkemizde daha sık olduğunu ancak BP sıklığının da ülkemizde de artmakta olduğunu söyleyebiliriz. Ayrıca OBH'nın, maliniteler ve nörolojik hastalıklar başta olmak üzere çeşitli hastalıklarla birlikte görülebilme ihtimali nedeniyle, detaylı araştııımaları gerektiğini vurgulamak istiyoruz. Çalışmamızın, ülkemizde bu konuyla ilgili yapılacak daha çok sayıda hasta içeren, daha kapsamlı, çok merkezli ve özellikle prospektif özellikte çalışmaların başlangıcı açısından faydalı olacağına inanıyoruz.

Yedi yıllık bir süreyi içeren çalışmamızın, yukarıda ilgili bölümlerde de değinilen ve özellikle retrospektif desenli olmasından kaynaklanan önemli sınırlııkları bulunmaktadır. Ancak diğer bölgelerden bildirilmiş raporlarla birlikte çalışmamızdan elde edilen sonuçların, OBH grubuna ilişkin ülkemizin genelini temsil etme niteliğine sahip, daha kapsamlı, çok merkezli ve özellikle prospektif desenli çalışmalara kaynak oluşturması açısından faydalı olacağına inanıyoruz.

\section{Kaynaklar}

1. Amagai M: Pemphigus. Dermatology. Ed. Bologna JL, Jorizzo JL, Rapini RP et al. 2'inci baskı. Mosby, 2008;417-29.

2. Borradori L, Bernard P. Pemphigoid group. Dermatology. Ed. Bologna JL, Jorizzo JL, Rapini RP et al. 2'inci baskı. Mosby, 2008;431-55.

3. Femiano F: Pemphigus vulgaris: recent advances in our understanding of its pathogenesis. Minerva Stomatol 2007:56:215-23.

4. Küçükoğlu R, Babuna G: Otoimmün büllöz hastalıkların klinik tanısı. Turkderm 2011;45 (özel sayı1):16-25

5. Schmidt E, Zillikens D: Pemphigoid diseases. Lancet 2013;381:320-32

6. Bertram F, Bröcker EB, Zillikens D, Schmidt E: Prospective analysis of the incidence of autoimmune bullous disorders in lower Franconia, Germany. J Dtsch Dermatol Ges 2009;7:434-40.

7. Daneshpazhooh M, Chams-Davatchi C, Payandemehr P, et al: Spectrum of autoimmune bullous diseases in Iran: a 10-year review. Int J Dermatol 2012;51:35-41
8. Nanda A, Dvorak R, Al-Saeed K, et al: Spectrum of autoimmune bullous diseases in Kuwait. Int J Dermatol 2004;43:876-81.

9. Langan SM, Smeeth L, Hubbard $\mathrm{R}$, et al: Bullous pemphigoid and pemphigus vulgaris-incidence and mortality in the UK:population based cohort study. BMJ 2008;337:a180.

10. Marazza G, Pham HC, Scharer L, et al: Incidence of bullous pemphigoid and pemphigus in Switzerland: a 2-year prospective study. Br J Dermatol 2009;161(4):861-8

11. Uzun S, Durdu M, Akman A et al: Pemphigus in the Mediterranean region of Turkey: A study of 148 cases. Int J Dermatol 2006;45:523-8.

12. Demircioğlu $D$, Bükülmez $G$, Atakan $N$, et al: Pemfigus vulgarisli hastaların klinik özellikleri ve tedaviye yanıtları: 6 yıllık Hacettepe deneyimi. Türkderm 2000; 34(4): 231-235

13. Akay BN, Bodamyalı P, Şanlı H, Akyol A: Büllöz pemfigoidli hastalarda 10 yıllık gözlem. Türkderm 2010;44:61-4

14. Erkin G: Otoimmün büllöz hastalıkların histopatolojik tanısı. Türkderm 2011;45 (özel sayı1):26-30

15. Uzun S: Otoimmün büllöz hastalıkların tanısında immünofloresan bulgular 2011:45 (özel sayı1):31-5

16. Ioannides D, Lazaridou E, Rigopoulos D: Pemphigus. J Eur Acad Dermatol Venereol 2008:22:1478-1496.

17. Michailidou EZ, Belazi MA, Markopoulos AK, et al: Epidemiologic survey of pemphigus vulgaris with oral manifestations in northern Greece: retrospective study of 129 patients. Int I Dermatol 2007;46:356-61

18. Woldegiorgis S, Swerlick RA: Pemphigus in the southeastern United States. South Med J 2001:94:694-8

19. Scully C, Paes De Almeida O, Porter SR, Gilkes JJ: Pemphigus vulgaris: the manifestations and long-term management of 55 patients with oral lesions. Br J Dermatol 1999;140:84-9.

20. Ljubojevic S, Lipozencic J: Autoimmune bullous diseases associations. Clin Dermatol 2012;30:17-33

21. Younus J, Ahmed AR: The relationship of pemphigus to neoplasia. J Am Acad Dermatol 1990;23:498-502

22. Ulusal HA, Su Ö, Cebeci F, Sakız D, Onsun N: Psöriasisli hastada büllöz pemfigoid gelişimi ve siklosporin ile ortak tedavi. Turkderm 2010;44:167-9

23. Gül Ü, Soylu S, Çakmak SK, Heper AO: Coexistence of pemphigus vulgaris with hashimoto's thyroiditis: case report. Turkiye Klinikleri J Dermatol 2009;19(1):51- 3

24. Gul Ü, Gonul M, Cakmak SK, Kilic A: Pemphigus vulgaris induced by honeybee sting?. Acta Derm Venereol 2006;86:476-8

25. Gul Ü, Gonul M, Soylu S, Heper AO, Demiriz M.: An unusual occurence of gastric adenocarcinoma in pemphigus vulgaris. Int J Dermatol 2009;48(9):1018-20

26. Cordel N, Chosidow O, Hellot MF, Delaporte E et al: Neurological disorders in patients with bullous pemphigoid. Dermatology 2007; 215(3):187-91

27. Ogawa $H$, Sakuma M, Morioka $S$ et al: The incidence of internal malignancies in pemphigus and bullous pemphigoid in Japan. J Dermatol Sci 1995;9(2):136-41

28. Iuliano L, Michelatta F, Natoli S: Bullous pemphigoid: an unusual and insidious presentation of breast cancer. Clin Oncol ( $\mathrm{R}$ Coll Radiol) 2003:15(8):505

29. Gül U, Kiliç A, Demirel O, Cakmak SK, Gönül M, Oksal A: Bullous pemphigoid associated with breast carcinoma. Eur J Dermatol 2006;16(5):581-2

30. Lindelöf B, Islam N, Eklund G, et al: Pemphigoid and cancer. Arch Dermatol 1990;126:66-8.

31. Guo L, Degenstein L, Dowling J, et al: Gene targeting of BPAG1: Abnormalities in mechanical strength and cell migration in stratified epithelia and neurologic degeneration. Cell 1995; 81(2):233-43.

32. Marzano AV, Tedechi A, Fanoni D et al: Activation of blood coagulation in bullous pemphigoid: role of eosinophils, and local and systemic implications. Br J Dermatol 2009;160:266-72

33. Risser J, Lewis K, Weinstock MA: Mortality of bullous skin disorders from 1979 through 2002 in the United States. Arch Dermatol 2009;145:1005-8.

34. Kharfi M, Khlaed A, Karaa A, Zaraa I et al: Linear IgA bullous dermatosis: The more frequent buloous dermatosis of children. Dermatol Online 2010;16:2. 